\title{
Effects of Reserpine Treatment on Dietary Adaptation of the Rat Exocrine Pancreas
}

\author{
DEE A. HAZLETT AND PATSY M. BRANNON
}

Department of Nutrition and Food Science, University of Arizona, Tucson, Arizona 85721

\begin{abstract}
Chronic reserpine treatment $(500 \mu \mathrm{g} / \mathrm{kg})$ of the rat results in generalized exocrinopathy, impaired pancreatic secretion, and decreased pancreatic amylase. These characteristics are similar to those in cystic fibrosis and are the basis for use of this experimental model for cystic fibrosis. Pancreatic enzymes adapt to diet, but it is not known whether chronic reserpine treatment affects this response. Due to the malnutrition induced by this treatment, another dose of reserpine was required that would alter pancreatic function but not induce malnutrition in order to evaluate dietary adaptation. Male rats (100-120 g) were injected subcutaneously daily for 7 days with 1) no injection (control); 2) $1.0 \mathrm{ml} / \mathrm{kg}$ vehicle or sham (pair fedsham); or 3) reserpine: 500,50 , or $5 \mu \mathrm{g} / \mathrm{kg}$. Food consumption was comparable among control and reserpine-treated $(50$ and $5 \mu \mathrm{g} / \mathrm{kg}$ ) rats and significantly greater $(200 \%)$ than pair fed-sham and $500 \mu \mathrm{g} / \mathrm{kg}$ reserpine-treated rats. Pancreatic amylase, however, was significantly lower in all reserpine-treated rats $(500 \mu \mathrm{g} / \mathrm{kg}, 74 \% ; 50 \mu \mathrm{g} / \mathrm{kg}, 56 \% ; 5$ $\mu \mathrm{g} / \mathrm{kg}, 52 \%$ ) than in control rats. To evaluate dietary adaptation, control and reserpine-treated $(5 \mu \mathrm{g} / \mathrm{kg})$ rats were fed high carbohydrate, high fat or high protein diets. Both groups adapted to these diets with the greatest amylase, lipase, and trypsin activities in high carbohydrate-, high fat-, and high protein-fed rats, respectively. Reserpine-treated rats fed high carbohydrate, however, had significantly lower $(64 \%)$ amylase activity than high carbohydrate-fed control rats. Although reserpine-treated rats can adapt pancreatic enzymes to diet, the adaptation of amylase to carbohydrate is impaired. (Pediatr Res 23: 176180, 1988)
\end{abstract}

\section{Abbreviations}

PFS, pair-fed sham

C, control

R500, reserpine-treated with $500 \mu \mathrm{g} / \mathrm{kg}$

R50, reserpine-treated with $50 \mu \mathrm{g} / \mathrm{kg}$

$R 5$, reserpine-treated with $5 \mu \mathrm{g} / \mathrm{kg}$

HC, high carbohydrate

HF, high fat

HP, high protein

ANOVA, analysis of variance

LSD, least significant difference

Received July 6, 1987; accepted September 30, 1987

Correspondence and reprints Patsy M. Brannon, 309 Shantz Building, University of Arizona, Tucson, AZ 85721.

Supported in part by Cystic Fibrosis Foundation New Investigator Award. Submitted in partial fulfillment of M.S. requirements, Graduate Program on Nutritional Sciences, University of Arizona [D.A.H.]. Presented in part at 1986 Triennial Joint Meeting-AIN, ASCN, CSNS (University of California, Davis CA) (Hazlett DA, Brannon PM 1986 Chronic reserpine treatment and dietary adaptation of the exocrine pancreas. Am J Clin Nutr 43:99a).
Rats chronically treated with reserpine $(500 \mu \mathrm{g} / \mathrm{kg})$ exhibit altered glycoprotein synthesis and secretion in the cells and ducts of salivary glands $(1,2)$, lungs $(3)$, and intestine $(4,5)$. Further, an electron-dense substance is observed obstructing the pancreatic acinar lumen (6), and some zymogen granules appear as less dense, mucin-containing vesicles (7). Abnormalities in the salivary gland include alterations in secretory volume, electrolyte and total protein concentrations $(8,9)$, and impaired epithelial $\mathrm{Cl}^{-}$transport (10). Pancreatic morphological abnormalities $(6$, 11, 12), impaired secretion (12-14), and decreased pancreatic amylase content $(13,14)$ occur in the reserpine-treated rat. These alterations are similar to those occurring in the human disease cystic fibrosis and are the basis for the use of this experimental animal model for cystic fibrosis $(1,6,8)$.

The underlying mechanisms of these effects of reserpine remain unknown. Even though reserpine depletes the brain and peripheral tissues of catecholamines, this does not appear to be the cause of these exocrine effects $(16,17)$. Reserpine may exert its effect directly on the exocrine cell or indirectly on cellular metabolism. In vitro reserpine treatment of colonic cells increases mucus production to the same extent as in vivo reserpine treatment $(5,16)$. Similarly, in vitro reserpine treatment of pancreatic acinar cells decreases pancreatic amylase activity and total protein synthesis to the same extent as in vivo reserpine treatment (17). The similarity of in vitro and in vivo reserpine treatment in these cells supports a direct cellular effect.

Chronic reserpine treatment also decreases food consumption $(14,15)$ and growth in rats and mice $(4,13-15)$, resulting in malnutrition (14). Pancreatic protein and amylase activity are decreased similarly in chronically reserpine-treated and PFS rats (restricted to the food consumption of the chronically reserpinetreated rats), but pancreatic amylase secretion is significantly less in acini isolated from chronically reserpine-treated rats compared to acini from PFS rats. These results indicate that some effects of reserpine, but not all, may be due to the induced malnutrition (14).

Although chronic reserpine treatment alters pancreatic function, it is not known whether this treatment also affects the adaptation of pancreatic enzymes to diet. Pancreatic secretions always contain amylase, lipase, and the proteases trypsin and chymotrypsin; but the exact composition varies according to dietary intake. A change in diet leads to an alteration in substrate available for hydrolytic enzymes and to a synchronous adaptive response by the pancreas. Amylase content in pancreas and pancreatic juice increases 2- to 3-fold when dietary starch or glucose increases from 20 to $75 \%(\mathrm{w} / \mathrm{w})(18,19)$. This adaptation results in an increase in the synthetic rate (4- to 5-fold) of amylase $(19,20)$ and the amount of mRNA $(1.8$ - to 2.0-fold) $(21)$. Lipase content increases 2-fold with a high fat diet (corn oil or lard) (22). However, lipase activity is only increased when the fat content of food is between 47 and $75 \%$ of total calories (23). Chymotrypsinogen content and synthesis is highest with an $82 \%$ casein diet, while trypsinogen is highest with a $45 \%$ casein diet (24). However, the mRNAs coding for these proteases increase 
3.6- to 3.9-fold with a high protein diet (25). The adaptive response of these hydrolytic enzymes to their respective substrates begins within $24 \mathrm{~h}$ and reaches a maximum in 5-7 days $(18,26-30)$.

Herein we examined whether chronic reserpine treatment alters this dietary adaptation of the pancreas. Because reserpine treatment decreases food consumption that can limit the study of dietary effects, the first objective was to determine whether another dose of reserpine would affect pancreatic function similarly to the $500-\mu \mathrm{g} / \mathrm{kg}$ dose without decreasing food consumption. The effects on the secretory responsiveness of isolated pancreatic acini to the secretagogue carbachol of a dose of reserpine that decreased amylase content without affecting food consumption were examined. Using a dose of reserpine that decreased pancreatic amylase content and secretory responsiveness without altering food consumption, the adaptive response of pancreatic enzymes to diet was evaluated in reserpine-treated $(5 \mu \mathrm{g} / \mathrm{kg})$ rats.

\section{MATERIALS AND METHODS}

Male Sprague-Dawley rats (100-120 g) were housed individually in hanging cages at $25^{\circ} \mathrm{C}$ with a 12 -h light/dark cycle. Rats had ad libitum access to water and Wayne Blox rodent food (Wayne Pet Food, Continental Grain Co., Chicago, IL) or purified diet, unless otherwise specified. To examine the reserpine dose response, rats were weight-matched into five groups and received subcutaneous injections daily for 7 days with 1) no injection (C); 2) $1.0 \mathrm{ml} / \mathrm{kg} 2 \%$ propylene glycol-8\% ethanol-5\% glacial acetic acid (PFS); or 3) reserpine: R500, R50, or R5. PFS rats were fed at $1630 \mathrm{~h}$ daily the amount of food consumed in the previous $24 \mathrm{~h}$ by the R500 rats. Reserpine (Sigma Chemical Co., St. Louis, MO) was dissolved in $0.05 \mathrm{ml}$ glacial acetic acid and diluted with $2 \%$ propylene glycol- $8 \%$ ethanol. The $\mathrm{pH}$ of the reserpine and vehicle solutions was adjusted to 4.5 with $\mathrm{NaHCO}_{3}$. To study dietary adaptation, rats were weight-matched into three groups fed HC, HF, or HP purified diets (Table 1). Each dietary group was subdivided into two treatment groups: $\mathrm{C}$ and R5. Food consumption and body weights were determined daily. Rats in the fed state were killed on day 8 of treatment between 0900-1030 h. The pancreata were removed and frozen at $-80^{\circ} \mathrm{C}$.

Pancreata were homogenized as described previously (14) in phosphate-buffered saline and centrifuged at $16,000 \times \mathrm{g}$, and $4^{\circ} \mathrm{C}$ for $30 \mathrm{~min}$. An aliquot of the supernatant was removed for proteolytic analysis, and soybean trypsin inhibitor (final concentration $0.1 \%$ ) was added to the remaining supernatant. The supernatant was analyzed for amylase (EC 3.2.1.1) by the Phadebas method (31) using certified amylase standards, for protein by the Lowry method using bovine serum albumin as the standard (32), and for lipase (EC 3.1.1.3) by a titrimetric method (33). For proteolytic analyses, the supernatant was activated as described previously (34) with $4 \%$ enterokinase at $25^{\circ} \mathrm{C}$ in a $\mathrm{pH}$

Table 1. Composition of purified diets*

\begin{tabular}{lccc}
\hline \multicolumn{1}{c}{ Component } & $\begin{array}{c}\mathrm{HC} \\
(\% \mathrm{cal})\end{array}$ & $\begin{array}{c}\mathrm{HF} \\
(\% \mathrm{cal})\end{array}$ & $\begin{array}{c}\mathrm{HP} \\
(\% \mathrm{cal})\end{array}$ \\
\hline Casein & 20.7 & 20.7 & 67.0 \\
DL-Methionine & 0.3 & 0.3 & 0.3 \\
AIN mineral mixture & 0.3 & 0.3 & 0.3 \\
AIN vitamin mixture & 1.0 & 1.0 & 1.0 \\
Choline bitartrate & & & \\
Cellulose & & & \\
Corn oil & 10.4 & 67.0 & 10.4 \\
Cornstarch & 67.0 & 10.4 & 20.7 \\
\hline
\end{tabular}

* Modified from Snook (42).

$\dagger 0.2 \%$ by weight.

$\ddagger 5 \%$ by weight in $\mathrm{HC}$ and $\mathrm{HP} ; 35 \%$ by weight in $\mathrm{HF}$.

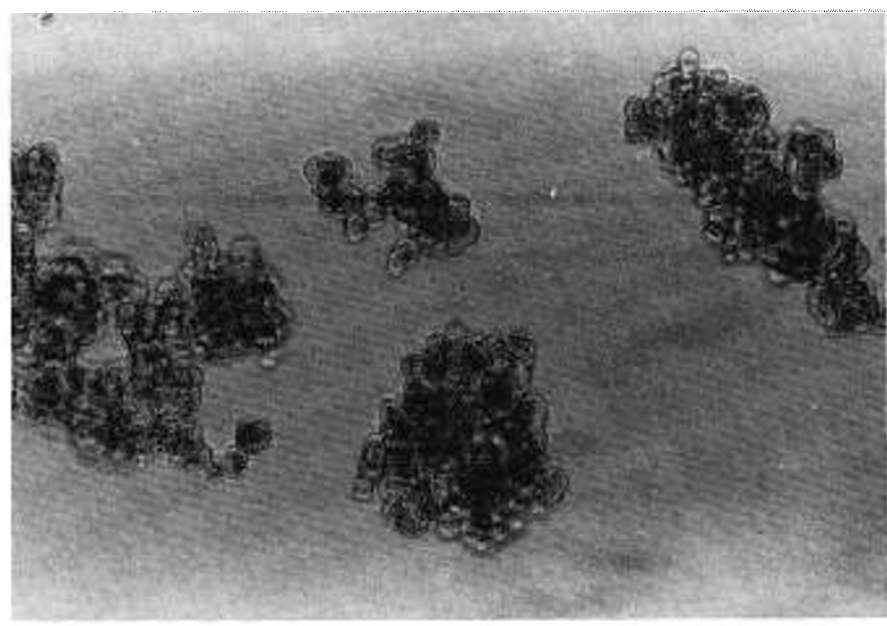

Fig. 1. Dispersed pancreatic acini isolated from control rat. (Phase contrast light micrograph, $\times 400$.)

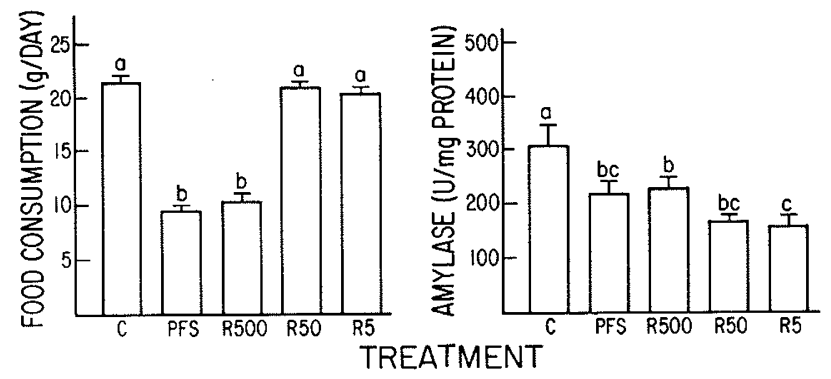

Fig. 2. Effects of various reserpine doses on food consumption and pancreatic amylase. Rats were fed Wayne rodent food, weight-matched into groups, and treated daily subcutaneously with injections as follows: 1) C, no injection and fed ad libitum ( $n=15) ; 2)$ PFS, $1.0 \mathrm{ml} / \mathrm{kg} 2 \%$ propylene glycol- $8 \%$ ethanol-5\% glacial acetic acid and fed the amount of food consumed by the R500 group ( $n=14)$; and 3) R500, $500 \mu \mathrm{g} / \mathrm{kg}$ reserpine $(n=9) ; \mathrm{R} 50,50 \mu \mathrm{g} / \mathrm{kg}$ reserpine $(n=9)$, or $\mathrm{R} 5,5 \mu \mathrm{g} / \mathrm{kg}$ reserpine $(n=9)$ and fed ad libitum. After 7 days, rats were killed and pancreata removed. Values are mean \pm SEM. ${ }^{a b c}$ Values for a given parameter not sharing a superscript are significantly different $(p<0.05)$ by ANOVA and LSD.

8.1 Tris buffer containing $0.02 \mathrm{M} \mathrm{Ca}^{2+}$ for maximal enzyme activity. The activated supernatant was then analyzed for chymotrypsin (EC 3.4.21.1) with glutaryl-phenylalanine para-nitroanilide (35) and for trypsin (EC 2.3.21.4) with benzoyl-arginine para-nitroanilide (36).

To study secretory responsiveness, pancreatic acini were isolated from C, PFS, R500, and R5 rats by a modified procedure of Bruzzone and coworkers (37). These modifications included a longer digestion $(15 \mathrm{~min})$ with collagenase in a shaking water bath at $37^{\circ} \mathrm{C}$ and 200 cycles/min, separation of exocrine from endocrine tissue through 3\% Ficoll (Sigma Chemical Co., St. Louis, MO) $5 \%$ calf serum (GIBCO, Grand Island, NY) gradient, and use of $10^{-5} \mathrm{M}$ carbachol (Sigma Chemical Co.) as the secretagogue. Pancreatic acini isolated from a control rat by this procedure showed dispersion of the isolated acini with exposure of numerous basal membranes by light microscopy (400×, Fig. 1). Trypan blue exclusion was similar among acini from all groups $(>90 \%)$. Isolated acini were preincubated for $30 \mathrm{~min}$ at $37^{\circ} \mathrm{C}$, allowed to settle via gravity, and were then incubated for 0 or $30 \mathrm{~min}$ in the presence of (stimulated) or in the absence of (basal) carbachol. Samples of the medium and cells were removed at 0 and $30 \mathrm{~min}$ and were centrifuged at $15,600 \times g$ for $20 \mathrm{~s}$. The media supernatant and cellular pellet from 0 - and $30-\mathrm{min}$ samples were analyzed for amylase activity. Amylase release was expressed as the percentage of amylase release (percent of the 
Table 2. Effects of various reserpine doses on body wt, pancreas $w t$, and lipase activity*

\begin{tabular}{|c|c|c|c|c|}
\hline \multirow[b]{2}{*}{ Treatment } & \multirow[b]{2}{*}{$\begin{array}{c}\text { Body wt } \\
\text { (g) }\end{array}$} & \multicolumn{3}{|c|}{ Pancreatic } \\
\hline & & $\begin{array}{l}\text { Wt } \\
(\mathrm{g}) \\
\end{array}$ & $\begin{array}{c}\text { Protein } \\
(\mathrm{mg})\end{array}$ & $\begin{array}{l}\text { Lipase } \\
\text { (U/mg } \\
\text { protein) }\end{array}$ \\
\hline Control & $175 \pm 2 \dagger^{a}$ & $0.89 \pm 0.02^{a}$ & $108 \pm 4^{a}$ & $50 \pm 4$ \\
\hline PFS & $108 \pm 2^{c}$ & $0.59 \pm 0.02^{b}$ & $83 \pm 5^{b}$ & $43 \pm 3$ \\
\hline R500 & $103 \pm 7^{c}$ & $0.63 \pm 0.04^{b}$ & $89 \pm 6^{b}$ & $44 \pm 6$ \\
\hline R50 & $162 \pm 3^{b}$ & $0.94 \pm 0.04^{a}$ & $124 \pm 12^{a}$ & $34 \pm 4$ \\
\hline R5 & $166 \pm 5^{a b}$ & $0.90 \pm 0.04^{a}$ & $112 \pm 9^{a}$ & $48 \pm 3$ \\
\hline
\end{tabular}

* Values are mean \pm SEM. Rats were fed Wayne rodent food, weightmatched into groups, and treated daily with subcutaneous injections as follows: 1) C, no injection and fed ad libitum ( $n=15)$; 2) PFS, $1.0 \mathrm{ml} /$ $\mathrm{kg} 2 \%$ propylene glycol-8\% ethanol-5\% glacial acetic acid and fed the amount of food consumed by the R500 group ( $n=14)$; and 3) R500, $500 \mu \mathrm{g} / \mathrm{kg}$ reserpine $(n=9) ; \mathrm{R} 50,50 \mu \mathrm{g} / \mathrm{kg}$ reserpine $(n=9) ;$ or $\mathrm{R} 5,5$ $\mu \mathrm{g} / \mathrm{kg}$ reserpine $(n=9)$ and fed ad libitum.

$\dagger^{a b c}$ Values for a given parameter not sharing a superscript are significantly different $(p<0.05)$ by ANOVA and LSD

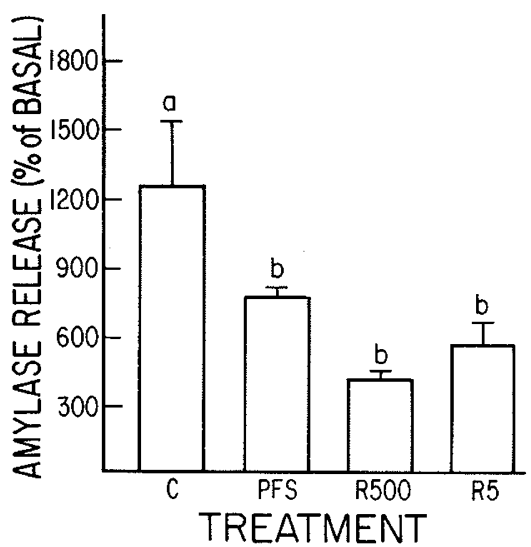

Fig. 3. Effects of different doses of reserpine on pancreatic amylase secretion. Rats were fed Wayne rodent food, weight-matched into groups, and treated with daily subcutaneous injections as described in Figure 2. Values are mean \pm SEM of six experiments for PFS and R5, five experiments for $\mathrm{C}$, and four experiments for R500. ${ }^{a b}$ Values for a given parameter not sharing a superscript are significantly different $(p<0.05)$ by ANOVA and LSD. total initial content) in the presence of secretagogue for $30 \mathrm{~min}$ to basal amylase release in the absence of secretagogue for 30 min.

Data (mean \pm SEM) were analyzed by one-way ANOVA and LSD (38) for the dose response and secretion studies. Two-way ANOVA and LSD (38) were used to analyze the data from the dietary adaptation studies to compare the independent effects of diet and treatment, as well as the interaction between diet and treatment.

\section{RESULTS}

Dose response. Food consumption was not altered in the $\mathrm{R} 50$ (96\%) and R5 (96\%) groups but was significantly $(p<0.001)$ decreased in the R500 (46\%) and PFS (48\%) groups compared to controls (Fig. 2). All reserpine doses significantly $(p<0.0002)$ decreased pancreatic amylase activity: $74 \%$ in R500, $56 \%$ in R50, and $52 \%$ in R5 compared to control (Fig. 2). Final body weights were significantly $(p<0.001)$ reduced in the $\mathrm{R} 500(58 \%)$, R50 (92\%), and PFS (62\%) groups when compared to control (Table 2). Pancreatic weights and protein were significantly $(p<$ 0.001 ) reduced only in the R500 (71 and $82 \%$ ) and PFS (66 and $77 \%$ ) groups (Table 2). Pancreatic lipase was not altered in any of the groups (Table 2). Because there was no significant difference between the 50 and $5 \mu \mathrm{g} / \mathrm{kg}$ doses, the $5 \mu \mathrm{g} / \mathrm{kg}$ dose was used for all subsequent studies. Carbachol-stimulated amylase release as a percentage of basal secretion was significantly $(p<$ $0.02)$ lower in acini from the R500 (35\%), R5 (46\%), and PFS (64\%) rats compared to that from control acini (Fig. 3).

Dietary adaptation. Food consumption was significantly $(p<$ $0.03)$ lower $(10 \%)$ in the HP-fed rats but was unaffected by reserpine treatment (Table 3 ). Body weight was not significantly altered by diet or reserpine treatment (Table 3). Pancreatic weight and protein were significantly $(p<0.001)$ higher in the HP-fed rats but were not affected by reserpine treatment (Table 3 ). Diet significantly affected all pancreatic enzyme activities $(\mathrm{U} / \mathrm{mg}$ protein) with the greatest amylase in HC-fed rats $(p<0.001)$, the greatest lipase activity in HF-fed rats $(p<0.001)$, the greatest trypsin activity in HP-fed rats $(p<0.002)$, and the lowest chymotrypsin activity in HP-fed rats $(p<0.01$, Table 3$)$. Only pancreatic amylase activity was significantly $(p<0.03)$ affected by reserpine treatment (Table 3) and was $64 \%$ lower in all reserpine-treated groups than controls. There was also a significant $(p<0.05)$ interaction of reserpine and diet on amylase activity (Table 3 ). Even though pancreatic amylase did adapt to

Table 3. Effects of chronic reserpine treatment and dietary composition in rat*

\begin{tabular}{|c|c|c|c|c|c|c|c|c|}
\hline \multirow[b]{2}{*}{ Diet } & \multirow{2}{*}{$\begin{array}{c}\text { Food } \\
\text { consumption } \\
\text { (g/day) }\end{array}$} & \multirow[b]{2}{*}{$\begin{array}{l}\text { Body wt } \\
\text { (g) }\end{array}$} & \multicolumn{6}{|c|}{ Pancreatic } \\
\hline & & & $\begin{array}{l}\text { Wt } \\
(\mathrm{g})\end{array}$ & $\begin{array}{l}\text { Protein } \\
\text { (mg) }\end{array}$ & Amylase & $\begin{array}{l}\text { Lipase } \\
(\mathrm{U} /\end{array}$ & $\begin{array}{l}\text { Trypsin } \\
\text { g protein) }\end{array}$ & Chymotrypsin \\
\hline \multicolumn{9}{|l|}{$\mathrm{HC}$} \\
\hline $\mathrm{C}$ & $18 \pm 1$ & $151 \pm 7$ & $0.76 \pm 0.03 \dagger^{b}$ & $89 \pm 2^{b}$ & $300 \pm 31^{a}$ & $43 \pm 5$ & $199 \pm 11^{a b}$ & $5.3 \pm 0.7$ \\
\hline R5 & $19 \pm 1$ & $150 \pm 5$ & $0.78 \pm 0.03^{b}$ & $92 \pm 5^{b}$ & $193 \pm 43^{b}$ & $51 \pm 7$ & $177 \pm 4^{b c}$ & $5.4 \pm 0.6$ \\
\hline \multicolumn{9}{|c|}{$101-4$} \\
\hline C & $18 \pm 1$ & $155 \pm 5$ & $0.79 \pm 0.07^{b}$ & $83 \pm 3^{b}$ & $36 \pm 4^{c}$ & $109 \pm 9$ & $185 \pm 12^{b c}$ & $5.5 \pm 0.6$ \\
\hline R5 & $17 \pm 1$ & $150 \pm 5$ & $0.73 \pm 0.03^{b}$ & $80 \pm 4^{b}$ & $31 \pm 4^{c}$ & $76 \pm 16$ & $151 \pm 7^{c}$ & $5.0 \pm 0.8$ \\
\hline \multicolumn{9}{|r|}{$0.0-0.0$} \\
\hline C & $16 \pm 1$ & $144 \pm 4$ & $0.97 \pm 0.05^{a}$ & $121 \pm 7^{a}$ & $80 \pm 9^{c}$ & $62 \pm 12$ & $233 \pm 25^{a}$ & $3.7 \pm 0.3$ \\
\hline R5 & $16 \pm 1$ & $139 \pm 7$ & $0.98 \pm 0.05^{a}$ & $131 \pm 9^{a}$ & $69 \pm 12^{c}$ & $56 \pm 9$ & $232 \pm 33^{a}$ & $3.7 \pm 0.1$ \\
\hline \multicolumn{9}{|l|}{ ANOVA $(p)$} \\
\hline Diet & 0.03 & NS & 0.001 & 0.001 & 0.001 & 0.001 & 0.002 & 0.01 \\
\hline Treatment & NS & NS & NS & NS & 0.03 & NS & NS & NS \\
\hline $\begin{array}{l}\text { Diet } \times \text { treat- } \\
\text { ment }\end{array}$ & NS & NS & NS & NS & 0.05 & NS & NS & NS \\
\hline
\end{tabular}

* Values are mean \pm SEM of six rats. Rats were weight-matched into groups, fed their respective diets ad libitum for 7 days, and treated daily with subcutaneous injections as follows: 1) $\mathrm{C}$, no injection and 2) $\mathrm{R} 5,5 \mu \mathrm{g} / \mathrm{kg}$ reserpine.

$\dagger^{a b c}$ Values for a given parameter not sharing a superscript are significantly different $(p<0.05)$ by ANOVA and LSD. NS, nonsignificant effect $(p>0.05)$. 
$\mathrm{HC}$ diet in both $\mathrm{C}$ and $\mathrm{R} 5$ rats, this adaptation was significantly impaired in the $\mathrm{R} 5$ rats compared to $\mathrm{C}$ rats (Table 3 ).

\section{DISCUSSION}

Malnutrition or fasting in the rat can lead to a nonparallel decrease in pancreatic enzymes $(14,29)$. These factors, therefore, can limit studies on dietary effects in the chronically reserpinetreated rat. By using lower doses of reserpine these complications were eliminated. Pancreatic amylase was significantly altered by a 50 or $5 \mu \mathrm{g}$ dose of reserpine, even when there was no decrease in food consumption. These results suggest that the alterations of pancreatic amylase by reserpine are not secondary to malnutrition.

The lower dose of reserpine also decreased pancreatic amylase secretion. This secretion was decreased in the R500, R5, and PFS rats. In a previous study, pancreatic acini from rats treated with $500 \mu \mathrm{g} / \mathrm{kg}$ reserpine secrete significantly less amylase in response to cholecystokinin than do acini from control rats, while acini from PFS rats show intermediate secretion between reserpine-treated and control acini (14). In the present study using $10^{-5} \mathrm{M}$ carbachol, amylase secretion by acini from PFS rats also tended to be intermediate between that of C and R500 or R5 acini.

In agreement with other studies, body weight was not altered by diet in this study $(20,21)$. Pancreatic weights, however, were significantly greater in rats fed HP diet than those fed $\mathrm{HC}$ and HF diets in the present study. In another study, pancreatic weight was greater in rats fed HP than HC diet (40), but one other study showed no alterations in pancreatic weights in rats fed HP and $\mathrm{HC}$ diets (21). Herein, pancreatic protein was greater in rats fed $\mathrm{HP}$ diet than in rats fed $\mathrm{HC}$ and $\mathrm{HF}$ diets.

In this study, pancreatic amylase from control and reserpinetreated rats did adapt to $\mathrm{HC}$ diet. Amylase activity was 7 -fold higher with $\mathrm{HC}$ than with $\mathrm{HF}$ diet and 3-fold higher than with HP diet. The changes in amylase with diet reported herein are similar to those reported in other studies $(22,23,27,28,30,39$ 41). Also, herein, pancreatic lipase from control and reserpinetreated rats adapted to HF diet. Lipase activity was 2-fold higher with $\mathrm{HF}$ than with $\mathrm{HC}$ diet and 1.6-fold higher than with $\mathrm{HP}$ diet. The 2 -fold or $100 \%$ increase in lipase activity with HF diet compared to an HC diet was comparable to other studies (22).

In both control and reserpine-treated rats, trypsin activity was 1.4-fold higher with HP than with HF diets and 1.2-fold higher than with $\mathrm{HC}$ diet in the present study compared with $1.5-$ to 1.7-fold higher with HP than with HC diets in another study (18). Contrary to other reports, pancreatic chymotrypsin activity was decreased in control and reserpine-treated rats fed HP diet compared to $\mathrm{HC}$ and HF diets herein. Other studies show that chymotrypsin is synthesized in direct proportion to the dietary substrate (24) and its activity is 2- to 3 -fold higher with HP than with HC diets (18). These differences in the response of chymotrypsin to dietary protein cannot be readily explained.

Even though amylase adapted to diet in reserpine-treated rats, amylase content was still significantly lower in all reserpinetreated rats than in controls. Further, its adaptation to dietary carbohydrate was impaired in reserpine-treated rats compared to controls. This decreased amylase content raises the possibility that reserpine treatment modifies amylase synthesis, degradation, or secretion. Enzyme content can be decreased by decreased synthesis, increased degradation, or increased secretion. Herein we demonstrated that reserpine treatment decreased secretion suggesting that the decreased amylase content was not due to this change in secretion. The most likely mechanisms of this change are a decrease in synthesis or an increase in degradation or both, but the present data do not distinguish among these possibilities. The rates of synthesis may be altered at the transcriptional or translational levels. Further research is required to determine whether reserpine decreases pancreatic amylase content by decreasing its rate of synthesis or increasing its rate of degradation.
Results from the present study indicate that treatment of rats with a lower dose of reserpine can alter pancreatic amylase content without affecting nutritional status. Reserpine does not alter the adaptation of pancreatic lipase, trypsin, and chymotrypsin to diet, but does impair the adaptation of pancreatic amylase to dietary carbohydrate. These results suggest that reserpine may modify the regulation of pancreatic amylase.

\section{REFERENCES}

1. Martinez JR, Adelstein E, Quissell D, Barbero GJ 1975 The chronically reserpinized rat as a possible model for cystic fibrosis. I. Submaxillary gland morphology and ultrastructure. Pediatr Res 9:463-469

2. Martinez JR, Bylund DB, Mawhinney T, Camden J, Ray G 1983 The chronically reserpinized rat as a model for cystic fibrosis: alterations in the mucussecreting sublingual gland. Pediatr Res 17:523-528

3. Thompson FE, Quissel DO, Williams CH, Martinez JR 1976 The chronically reserpinized rat as a possible model for cystic fibrosis: IV. The protein composition of pulmonary lavage fluid. Pediatr Res 10:632-635

4. Forstner J, Maxwell B, Roomi N 1981 Intestinal secretion of mucin in chronically reserpine-treated rats. Am J Physiol 241:6443-6450

5. Brady RC, Dedman JR 1982 Reserpine-induced mucus hypersecretion, in vitro and in vivo, entails a loss of distinct calmodulin acceptor proteins. $J$ Cell Biol 195:397a

6. Roomans GM, Wei X, Ceder O, Kollberg H 1982 The reserpinized rat in the study of cystic fibrosis: $\mathrm{x}$-ray microanalysis of submandibular gland and pancreas. Ultrastruct Pathol 3:285-293

7. Werlin SL, Harb JM, Stefaniak J, Taylor T 1983 Pancreatic structure and function in the immature reserpinized rat. Exp Mol Pathol 39:24-36

8. Martinez JR, Adheads PC, Quissell D, Barbero GJ 1975 The chronically reserpinized rat as a possible model for cystic fibrosis. II. Composition and cilioinhibitory effects of submaxillary saliva. Pediatr Res 9:470-475

9. Wood DL, Martinez JR 1977 The chronically reserpinized rat as a possible model for cystic fibrosis. VI. Synergistic effects of isoproterenol for $\mathrm{Ca}^{++}$and protein in the submaxillary gland. Pediatr Res 11827-11832

10. Martinez JR, Cassity N 1985 The chronically reserpinized rat as a model for cystic fibrosis: abnormal $\mathrm{Cl}^{-}$transport as the basis for reduced salivary fluid secretion. Pediatr Res 19:711-716

11. Setser ME, Spicer SS, Simson JAV, Adamson M, Martinez JR 1979 The effects of reserpine on the ultrastructure secretory responses of rat exocrine pancreas. Exp Mol Pathol 32:413-422

12. McCurdy RE, Martinez R 1981 The chronically reserpinized rat as a model for cystic fibrosis: alterations in pancreatic enzyme secretion and storage. Pediatr Res 15:1308-1313

13. Joehl RJ, DeJoseph MR 1985 Pancreatic enzyme secretion in experimental cystic fibrosis. In: Martinez JR, Barbero GJ (eds) Animal Models for Cystic Fibrosis: The Reserpine-treated Rat. San Francisco, CA, pp 119-124

14. Hazlett D, Korc M, Brannon PM 1986 Effects of malnutrition and chronic reserpine treatment on pancreatic exocrine function. Pediatr Res 20:12361239

15. Sordelli DO, Cassino RJJ, Pivetta OH 1979 Animal model for cystic fibrosis: pulmonary clearance of Staphylococcus aureus in mice treated with reserpine. Life Sci 24:2003-2010

16. Brady RC, Karneky KJ, Dedman JR 1984 Reserpine-induced alterations in mucus production and calmodulin-binding proteins in a human epithelial cell line. Exp Cell Res 150:141-151

17. Brannon PM, Scott D 1987 Reserpine-treatment in vivo and in vitro alters pancreatic acinar function. In Vitro Cell Dev Biol 23:429-435

18. Ben Abdeljlil A, Visani AM, Desnuelle P 1963 Adaptation of the exocrine secretion of rat pancreas to the composition of the diet. Biochem Biophys Res Commun 10:112-116

19. Marchis-Mouren G, Pasero L, Desnuelle P 1963 Further studies on amylase biosynthesis by pancreas of rats fed on a starch-rich or a casein-rich diet. Biochem Biophys Res Commun 13:262-266

20. Reboud JP, Marchis-Mouren G, Cozzone A, Desnuelle P 1966 Variations in the biosynthesis rate of pancreatic amylase and chymotrypsinogen in response to a starch-rich diet or a protein-rich diet. Biochem Biophys Res Commun 22:94-99

21. Wicher C, Puigserver A, Scheele G 1984 Dietary regulation of levels of active mRNA coding for amylase and serine protease zymogena in the rat pancreas. Eur J Biochem 139:381-387

22. Bazin R, Lavau M, Herzog J 1978 Pancreatic lipase and ketogenic conditions. Biomedicine 28:160-165

23. Sabb JE, Godfrey PM, Brannon PM 1986 Adaptive response of rat pancreatic lipase to dietary fat: effects of amount and type of fat. J Nutr 116:892-899

24. Shick J, Verspohl R, Kern H, Scheele G 1984 Two distinct adaptive responses in the synthesis of exocrine pancreatic enzymes to inverse changes in protein and carbohydrate in the diet. Am J Physiol 247:G611-G616

25. Giorgi D, Renaud W, Bernard JP, Dagorn JC 1985 Regulation of proteolytic enzyme activities and mRNA concentrations in rat pancreas by food content. Biochem Biophys Res Commun 127:937-942

26. Howard F, Yudkin J 1963 Effect of dietary change upon the amylase and trypsin activities of the rat pancreas. Br J Nutr 17:281-294

27. Christophe J, Camus J, Deschodt-Lanckman M, Rathe J, Robberecht $P$ Vandermeers-Piret MC, Vandermeers A 1971 Factors regulating biosynthesis, intracellular transport and secretion of amylase and lipase in the rat exocrine pancreas. Horm Metab Res 3:393-403 
28. Johnson A, Hurwitz R, Kretchmer N 1977 Adaptation of rat pancreatic amylase and chymotrypsinogen to changes in diet. J Nutr 107:87-96

29. Snook JT 1965 Dietary regulation of pancreatic synthesis, secretion, and inactivation in the rat. J Nutr 87:297-305

30. Deschodt-Lanckman M, Robberecht P, Camus J, Christophe J 1971 Shortterm adaptation of pancreatic hydrolases to nutritional and physiological stimulation in adult rats. Biochimie 53:789-796

31. Ceska M, Birath K, Brown B 1969 A new and rapid method for the clinical determination of $\alpha$-amylase activities in human serum and urine. Clin Chem Acta 26:437-439

32. Lowry OH, Rosebrough NJ, Far AL, Randall RJ 1957 Protein measurement with the folin phenol reagent. J Biol Chem 193:265-275

33. Naher G 1974 Lipase titrimetric assay. In: Bergmeyer HU (ed) Methods of Enzymatic Analysis. Academic Press, New York, pp 814-818

34. Brannon PM, Collins VP, Korc M 1987 Alterations of pancreatic digestive enzyme content in the manganese-deficient rat. J Nutr 117:305-311
35. Erlanger BF, Edel F, Cooper AG 1966 The action of chymotrypsin on two new chromogenic substrates. Arch Biochem Biophys 115:206-210

36. Erlanger BF, Kokowsky N, Cohen W 1961 The preparation of two new chromogenic substrates of trypsin. Arch Biochem Biophys 95:271-278

37. Bruzzone R, Halban PA, Gjinovci A, Trimble ER 1985 A new, rapid, method for preparation of dispersed pancreatic acini. Biochem J 226:621-624

38. Steel RGO, Torie JH 1960 Principles and Procedures of Statistics. McGrawHill Book Co., Inc., New York

39. Bourdel G 1983 Effect of separate feeding of proteins and lipids on pancreatic adaptation in the rat. Am J Physiol 244:G125-G130

40. Snook JT 1971 Dietary regulation of pancreatic enzymes in the rat with emphasis on carbohydrate. Am J Physiol 221:1383-1387

41. Poort SR, Poort C 1981 Effect of feeding diets of different composition on the protein synthetic pattern of the rat pancreas. J Nutr 111:1475-1479

42. Snook JT 1971 Effects of diet on development of exocrine pancreas of the neonatal rat. Am J Physiol 221:1388-1391 